\title{
OTONOMI PENGELOLAAN SUMBER DAYA MANUSIA PTN-BH
}

\author{
Kartika Widya Utama \\ Fakultas Hukum Universitas Diponegoro \\ Jalan Profesor Soedarto, Tembalang, Kota Semarang, Jawa Tengah 50275 \\ Kartikawidyautama.undip@gmail.com
}

\begin{abstract}
As a new entity, PTN-BH requires regulation and review of existing rules to provide a sense of security to every stakeholder involved, either as regulators, regulators, or parties affected by the change of PTN status to PTN-BH. One of the important aspects of the implementation of PTN-BH is the management of human resources. This article will discuss some regulations related to HR PTN Legal Body especially regarding civil servants with normative juridical approach.
\end{abstract}

Keywords: PTN Legal Entity, Human Resources, ASN

\begin{abstract}
Abstrak
Sebagai sebuah entitas baru, PTN-BH membutuhkan pengaturan dan pengkajian aturan yang telah ada guna memberikan rasa aman terhadap setiap stakeholder yang terlibat, baik sebagai pembuat aturan, pelaksana aturan, atau pihak-pihak yang terdampak atas berubahnya status PTN menjadi PTN-BH. Salah satu aspek penting dalam penyelenggaraan PTN-BH adalah mengenai pengelolaan sumber daya manusia. Artikel ini akan membahas beberapa peraturan terkait SDM PTN Badan Hukum khususnya mengenai PNS dengan pendekatan yuridis normatif.
\end{abstract}

Kata Kunci: PTN Badan Hukum, Sumberdaya Manusia, ASN

\section{A. Pendahuluan}

Berhadapan dengan persaingan global, di bidang pendidikan khususnya pendidikan tinggi diwajibkan untuk mengembangkan diri. Pendidikan Tinggi di Indonesia hingga saat ini masih bertumpu pada Perguruan Tinggi Negeri sebagai ujung tombak, dibuktikan dengan pemeringkatan oleh lembaga-lembaga pemeringkatan Perguruan Tinggi didominasi oleh Perguruan Tinggi Negeri (PTN). Pemeringkatan yang dilakukan Kemenristekdikti ("Daftar 100 Peringkat Perguruan Tinggi Non-Politeknik di Indonesia tahun 2017 | Direktorat Jenderal Kelembagaan Iptek dan Dikti," n.d.) menunjukkan bahwa PTN adalah garda terdepan dalam mencerdaskan kehidupan anak bangsa di jenjang pendidikan tinggi.

Pada tingkat dunia, beberapa lembaga pemeringkat universitas seperti 4.icu("Top Universities in Indonesia | 2017 Indonesian University Ranking," n.d.), QS World University Ranking ("QS World University
Rankings 2018 | Top Universities,” n.d.), menempatkan universitas-universitas Indonesia, khususnya PTN diluar peringkat 200 besar dunia, dengan nama UGM dan UI sebagai universitas indonesia yang memiliki peringkat tertinggi. Hal ini tentu menunjukkan betapa jauh jarak yang harus ditempuh untuk bersaing di tingkat dunia, bahkan di Asia sekalipun. Salah satu upaya yang dilakukan oleh pemerintah, adalah dengan dibentuknya PTN BHMN pada tahun 2000, yang kini beralih nama menjadi PTN Badan Hukum pasca diterbitkannya UU No 12 Tahun 2012 tentang Pendidikan Tinggi. PTN Badan Hukum (PTN-BH) diharapkan dapat lebih produktif, manakala diberikan kemandirian yang mencakup otonomi, keadilan dan adaptabilitas(Wahab, 2004).

Pentingnya Otonomi juga disampaikan dalam laporan OECD mengenai pendidikan tinggi di Mesir dimana dalam meningkatkan produktivitas Perguruan Tinggi dan mengembangkan layanan yang prima diperlukan fleksibilitas dalam 
operasional serta perlunya meningkatkan kemampuan manajemen internal dari PTN itu sendiri (OECD, 2010). Otonomi pada PTN menjadi suatu hal yang mutlak apabila pemerintah ingin meningkatkan kapabilitas PTN untuk bersaing di tingkat Asia dan Dunia.

Salah satu otonomi yang diperlukan dalam penyelenggaran pendidikan tinggi yang berkualitas adalah otonomi di bidang pengelolaan Sumber Daya Manusia. Tanpa pengelolaan sumber daya yang mumpuni, sangat sulit untuk mewujudkan pengelolaan PTN yang mampu menghasilkan lulusan berkualitas dan berdaya saing (Shattock, 2002). Pengelolaan SDM berkaitan erat dengan kelembagaan PTN Badan Hukum itu sendiri, dimana diperlukan sebuah pengaturan yang mampu mengakomodasi fleksibilitas pengelolaan PTN-BH khususnya di bidang SDM. Terdapat 3 jenis aturan yang diperlukan terkait SDM di PTN-BH yakni kejelasan status kepegawaian, stuktur organisasi / nomenklatur jabatan PTN-BH dan jenjang karir bagi seluruh personel PTN$\mathrm{BH}$ baik ASN maupun tenaga tidak tetap. Tulisan ini akan membahas ketiga unsur tersebut melalui identifikasi dan analisis peraturan-peraturan yang ada, apakah telah memberikan otonomi sebagaimana dimaksud dalam UU No. 12 Tahun 2012 tentang Perguruan Tinggi atau tidak.

\section{B. Pembahasan}

\section{Status Kepegawaian Sumber Daya Manusia di Lingkungan PTN Badan Hukum}

Pembahasan Sumber Daya Manusia di lingkungan PTN BH akan dimulai dengan status kepegawaian SDM PTN BH . Peraturan terkait manajemen ASN secara umum diatur dalam Undang-Undang Nomor 5 Tahun 2014 tentang ASN, dimana istilah ASN merujuk kepada Pegawai Negeri Sipil (PNS) dan Pegawai Pemerintah dengan Perjanjian Kerja (P3K). PNS adalah adalah warga negara RI yang memenuhi syarat tertentu, diangkat sebagai pegawai ASN secara tetap oleh pejabat pembina kepegawaian untuk menduduki jabatan pemerintahan. PNS yang ditempatkan pada PTN-BH diangkat, dibina, dan diberhentikan oleh Menteri Riset,
Teknologi, dan Pendidikan Tinggi. Sedangkan Pegawai Pemerintah dengan Perjanjian Kerja selanjutnya disingkat PPPK adalah warga negara Indonesia yang memenuhi syarat tertentu, yang diangkat berdasarkan perjanjian kerja untuk jangka waktu tertentu dalam rangka melaksanakan tugas pemerintahan.

Perguruan Tinggi Negeri Badan Hukum (PTN BH) secara umum diatur dalam Undang-Undang No. 12 Tahun 2012 tentang Perguruan Tinggi dimana dalam Pasal 65 diatur bahwa:

(1) Penyelenggaraan otonomi Perguruan Tinggi sebagaimana dimaksud dalam Pasal 64 dapat diberikan secara selektif berdasarkan evaluasi kinerja oleh Menteri kepada PTN dengan menerapkan Pola Pengelolaan Keuangan Badan Layanan Umum atau dengan membentuk PTN badan hukum untuk menghasilkan Pendidikan Tinggi bermutu.

Berdasarkan pasal diatas jelas bahwa tujuan utama didirikannya PTN BH adalah untuk menghasilkan Pendidikan Tinggi bermutu, distingsi kata bermutu disini berarti bahwa PTN BH dituntut memiliki kualitas lebih mumpuni dibandingkan PTN-PTN non BH ( Creme-de-la-crème). Adapun salah satu kriteria perguruan Tinggi Bermutu adalah Perguruan Tinggi yang mampu memberi kepuasan pelanggannya dan memiliki daya saing dan tinggi (Purwandani \& Sutarsih, 2016). Lebih lanjut diatur dalam Pasal 65 ayat 3 UU Perguruan Tinggi:

(3) PTN badan hukum sebagaimana dimaksud pada ayat (1) memiliki:

a. kekayaan awal berupa kekayaan negara yang dipisahkan kecuali tanah;

b. tata kelola dan pengambilan keputusan secara mandiri;

c. unit yang melaksanakan fungsi akuntabilitas dan transparansi;

d. hak mengelola dana secara mandiri, transparan, dan akuntabel;

e. wewenang mengangkat dan 
memberhentikan sendiri Dosen dan tenaga kependidikan;

f. wewenang mendirikan bad an u s a a d an mengembangkan dana abadi; dan

g. we w e nang untuk $\mathrm{m}$ e $\mathrm{m}$ b u $\mathrm{k}$ a, menyelenggarakan, dan menutup Program Studi.

Ayat 3 huruf $b$ mengatur bahwa PTN BH memiliki tata kelola dan pengambilan keputusan secara mandiri dan huruf e mengatur bahwa PTN BH memiliki wewenang untuk mengangkat dan memberhentikan sendiri dosen dan tenaga kependidikan, namun dalam Pasal ini tidak dijelaskan siapa yang dimaksud dengan dosen dan tenaga kependidikan tersebut dan status perjanjian kerjanya.

Dosen dalam PTN BH dapat merupakan Pegawai Negeri Sipil yang diangkat oleh Kemenristekdikti dengan mekanisme seleksi PNS, dapat pula dosen profesional yang diangkat oleh PTN BH melalui seleksi mandiri atau disebut juga sebagai dosen tetap PTN-BH Non PNS, dapat pula merupakan dosen profesional yang diikat dalam perjanjian kerja dalam waktu tertentu. Hal yang sama berlaku pula pada tenaga kependidikan yang dapat berstatus PNS, pegawai tetap Non-PNS dan pegawai tidak tetap atau kontrak.

$\mathrm{P}$ e $\mathrm{r}$ b e d a $\mathrm{n}$ s t a t u s kepegawaian baik dosen maupun tenaga kependidikan berpengaruh pada aturan hukum mana yang berlaku. Dalam pasal 65 ayat 3 tidak dijelaskan atau diatur apa akibat dari perbedaan status tersebut, sehingga hal ini menimbulkan kekosongan aturan yang tentu menyulitkan dan bahkan berbahaya bagi para stakeholder terkait, khususnya bagi para pengambil kebijakan di PTN$\mathrm{BH}$. Aturan terkait dengan perbedaan status kepegawaian tersebut dapat ditemukan dalam statuta masingmasing PTN-BH yang diatur dalam bentuk Peraturan Pemerintah.

Sebagai contoh, Universitas Indonesia dengan PP No. 68 Tahun 2013, Pasal 42 menyatakan bahwa Pegawai dalam lingkungan UI sebagaimana dimaksud pada ayat (1) terdiri atas:

a.pegawai negeri sipil yang dipekerjakan;

b. pegawai tetap; dan

c. pegawai tidak tetap.

Bagi pegawai tetap dan tidak tetap dalam hal hak dan kewajibannya diatur tersendiri dengan peraturan Rektor sebagai perwujudan otonomi PTN-BH, sehingga tidak menjadi sebuah permasalahan. Namun, untuk pegawai yang berstatus PNS yang dipekerjakan berlaku ketentuan dalam Pasal 42 ayat 5 yang berbunyi "Gaji pegawai negeri sipil yang dipekerjakan sebagaimana dimaksud pada ayat (2) huruf a, dibayar sesuai dengan ketentuan peraturan perundang-undangan". Dibayar sesuai dengan ketentuan peraturan perundangundangan tersebut merujuk pada Peraturan Pemerintah Republik Indonesia Nomor 9 Tahun 2003 Tentang Wewenang Pengangkatan, Pemindahan, Dan Pemberhentian Pegawai Negeri Sipil Pegawai Negeri Sipil yang diperbantukan adalah Pegawai Negeri Sipil yang melaksanakan tugas di luar instansi induknya yang gajinya dibebankan pada instansi yang menerima perbantuan.

Hal ini kemudian menimbulkan sebuah pertanyaan yang menarik, yaitu apakah PNS yang bekerja di keempat PTN$\mathrm{BH}$ sudah tidak dianggap lagi sebagai PNS Pusat? Hal ini beralasan karena struktur kelembagaan PTN-BH sendiri pada saat itu belum jelas dan pengaturan terkait dengan PTN-BH masih bersifat umum. PTN-BH diposisikan sebagai suatu lembaga mandiri yang terpisah secara struktural kelembagaan dengan alat perlengkapan Negara lainnya di bidang pendidikan yang dibentuk berdasarkan amanat Undang-undang Pendidikan Tinggi dan berada dalam koordinasi di bawah Kemenristekdikti.

Hal yang berbeda manakala kita 
melihat pada statuta PTN-BH yang baru-baru ini ditetapkan sebagai PTN-BH, Universias Diponegoro dengan Peraturan Pemerintah No 52. Tahun 2015 Pasal 55 menyatakan bahwa pegawai Undip terdiri atas Pegawai Negeri Sipil dan Non-Pegawai Negeri sipil. Dengan penegasan status Pegawai Negeri Sipil tanpa adanya embel-embel dipekerjakan atau diperbantukan, menegaskan bahwa PNS yang dimaksud dalam pasal tersebut memiliki hak dan kewajiban yang sama sesuai peraturan perundang-undangan yang berlaku mengenai PNS pada umumnya. Dengan demikian PNS di lingkungan Universitas Diponegoro tetap sebagai pegawai Kementerian Riset Teknologi dan Pendidikan Tinggi sebagai instansi pusat.

Dua bentuk pengaturan diatas tentu membawa konsekuensi dalam penganggaran dan pengelolaan keuangan PTN-BH, apabila merujuk pada bentuk PP PTN-BH yang lama, penulis berpendapat bahwa bentuk semacam itu justru memberatkan PTN-BH bersangkutan karena dapat dipersepsikan bahwa PNS yang bekerja di PTN-BH tersebut bukan lagi menjadi bagian dari pegawai Kementerian Riset, Teknologi dan Pendidikan Tinggi. Implikasi lebih lanjut dengan pemahaman demikian adalah PTN$\mathrm{BH}$ dapat dianggap sebagai Badan Hukum Privat yang dilepaskan dari tanggung jawab negara, sehingga diperlukan penegasan bahwa PTN-BH adalah bagian dari alat perlengkapan negara di bidang pendidikan tinggi yang dalam hal ini melaksanakan amanat Undang-undang Perguruan Tinggi sebagai Badan Hukum Publik sesuai dengan Putusan Mahkamah Konstitusi. Kejelasan status kepegawaian PTN-BH sangat penting untuk memenuhi tiga kriteria utama dalam keberhasilan pengelolaan suatu organisasi dalam hal ini PTN-BH, yaitu service quality, customer satisfaction and behavioral intentions (Alma \& Hurriyati, 2008).

\section{Struktur Organisasi PTN Badan Hukum}

Struktur organisasi PTN Badan Hukum berpengaruh besar terhadap jenjang karir dan manajemen pengelolaan sumber daya manusia di PTN BH tersebut. Struktur organisasi PTN-BH berdasarkan Pasal 30
Peraturan Pemerintah No. 4 Tahun 2014 tentang Penyelenggaraan dan Pengelolaan Perguruan Tinggi hanya mengatur bahwa struktur PTN-BH terdiri dari sekurangkurangnya:

(1) Organisasi PTN Badan Hukum paling sedikit terdiri atas:

a. majelis wali amanat sebagai unsur penyusun kebijakan sebagaimana dimaksud dalam Pasal 28 huruf a yang menjalankan fungsi penetapan, pertimbangan pelaksanaan kebijakan u m u m, dan pengawas a n nonakademik;

b. Pemimpin Perguruan Tinggi sebagai unsur pelaksana akademik sebagaimana dimaksud dalam Pasal 28 huruf $b$, yang menjalankan fungsi Pengelolaan Perguruan Tinggi dan bertanggung jawab kepada majelis wali amanat; dan

c. senat akademik yang menjalankan fungsi penetapan kebijakan, pemberian pertimbangan, dan pengawasan di bidang akademik.

d. dewan penyantun atau nama lain yang menjalankan fungsi pertimbangan nonakademik dan fungsi lain yang ditetapkan dalam Statuta.

Frasa "paling sedikit terdiri dari" dalam Pasal diatas mengakibatkan legalitas struktur organisasi dalam PTN-Badan Hukum yang tegas diakui secara hukum adalah keempat unsur saja. Terbuka kemungkinan adanya struktur organisasi PTN Badan Hukum selain empat unsur tersebut, sesuai dengan kebutuhan dan proyeksi pengembangan PTN Badan Hukum tersebut ke depan. Struktur organisasi diluar empat unsur tersebut diserahkan kepada kebijakan dan kebutuhan masing-masing PTN-BH, dengan demikian mengakibatkan terbukanya keberagaman struktur organisasi yang berbeda-beda antara satu PTN-BH dengan PTN-BH lainnya.

Keberagaman struktur organisasi yang berbeda-beda merupakan akibat yang tidak terelakkan sebagai akibat dari frasa "paling sedikit terdiri dari" dan tidak ada pembatasan mengenai struktur organisasi selain dari syarat minimal yang dipersyaratkan harus dimiliki oleh PTN-BH. 
Secara internal PTN-BH, pengakuan atas struktur organisasi yang dibentuk dan ditetapkan oleh PTN BH tersebut tentu tidak menimbulkan permasalahan. Permasalahan yang timbul adalah pengakuan atas struktur organisasi PTN-Badan Hukum oleh Kementerian terkait.

Kemudian dalam ayat 9 "Ketentuan lebih lanjut mengenai organisasi dan tata kelola PTN Badan Hukum sebagaimana dimaksud pada ayat (1) sampai dengan ayat (8) diatur dalam Peraturan Pemerintah tentang Statuta masing-masing PTN Badan Hukum. Peraturan Pemerintah No. 52 Tahun 2015 tentang Statuta Undip mengatur bahwa kewenangan mengenai nomenklatur, pembidangan tugas dan wewenang, pembentukan, penyelenggaraan, perubahan, dan penutupan unsur di bawah Rektor diatur dengan peraturan Rektor.

UU No 12 tahun 2012 tentang Perguruan Tinggi dan aturan-aturan turunannya tidak memberikan pengaturan secara tegas mengenai struktur organisasi PTN-BH dan hanya memberikan syarat minimal. Pemberian kewenangan tanpa adanya batasan yang jelas tersebut dapat menimbulkan permasalahan di kemudian hari. Bagaimanapun, inti dari negara hukum adalah adanya keterikatan masyarakat dan pejabat / badan tata usaha negara yang dalam setiap tindakannya diatur oleh aturan Hukum (Tamanaha, 2007). Salah satu fungsi negara hukum adalah untuk membatasi tindakan pejabat / badan tata usaha negara melalui konsep rule by law, yang kemudian berkembang dalam bentuk legalitas formal sebuah aturan hukum yakni bersifat umum, jelas, prospektif dan pasti serta menonjolkan kepastian hukum secara formal.

Apabila dimaknai bahwa aturan terkait struktur organisasi PTN-BH tidak memberikan batasan jelas dalam rangka memberikan otonomi seluas-luasnya kepada PTN-BH merupakan hal yang sah-sah saja. Namun dalam pelaksanaannya, khususnya terkait dengan pengakuan akan keabsahan struktur organisasi tersebut menjadi suatu hal yang bergantung kepada diskresi pejabat yang berwenang untuk memberikan pengakuan, dalam hal ini Menteri Aparatur Sipil Negara dan Reformasi Birokrasi. Perlu diperjelas kewenangan Rektor selaku pimpinan PTN$\mathrm{BH}$ untuk menyusun dan membentuk struktur organisasi sesuai dengan statuta masingmasing PTN-BH.

Kewenangan memiliki kedudukan yang penting dalam kajian hukum tata negara dan hkum administrasi negara. Begitu pentingnya kedudukan kewenangan ini, sehingga F.A.M. Stroink dan J.G. Steenbeek menyebut sebagai konsep inti dalam hukum tata negara dan hukum administrasi negara (Ridwan, 2013). Philipus M. Hadjon, mengatakan bahwa setiap tindakan pemerintahan disyaratkan harus bertumpu atas kewenangan yang sah. Kewenangan itu diperoleh melalui tiga sumber, yaitu atribusi, delegasi, dan mandat. Kewenangan atribusi lazimnya digariskan melalui pembagian kekuasaan negara oleh undang-undang dasar, sedangkan kewenangan delegasi dan mandat adalah kewenangan yang berasal dari pelimpahan.

Kewenangan untuk membentuk stuktur organisasi selain keempat unsur minimal diatas dengan demikian merupakan bentuk pendelegasian kewenangan dari Kemenristekdikti kepada PTN-BH selaku pelaksana penyelenggaraan pendidikan tinggi badan hukum. Struktur organisasi berikut dengan nomenklatur organisasi yang dibentuk oleh PTN-BH sudah seharusnya diakui oleh Kemenristekdikti selaku pemberi delegasi. Penegasan ini menjadi penting untuk meminimalkan diskresi-diskresi yang perlu dibuat oleh pimpinan PTN-BH, sehingga tidak muncul diskresi-diskresi kreatif yang justru membahayakan pejabat yang bersangkutan.(Irawan, 2011).

\section{Jenjang Karir}

Logemann (J.H.A, 1995) mengatakan bahwa Negara dan organisasi jabatan "de staat is ambtenorganisatie dan dalam suatu Negara itu ada jabatan pemerintahan, yakni lingkungan pekerjaan tetap yang dilekati dengan wewenang untuk menyelenggarakan urusan pemerintahan,. Tugas dan wewenang yang melekat pada jabatan ini dijalankan oleh manusia (natuurlijke persoon), yang bertindak selaku pelaksana kewenangan dan disebut sebagai pejabat. Penggunaan wewenang oleh pejabat selalu disertai dengan 
tanggung jawab, sesuai dengan prinsip "deen bevoegdheid zonder verantwoordenlijkheid" ( t idak ada kewenangan tanpa pertanggungjawaban). Karena kewenangan selalu melekat pada jabatan, akan tetapi dalam pelaksanaannya, kewenangan tersebut dijalankan oleh manusia selaku pejabat.

Manusia memerlukan kepastian dalam hidupnya, tidak terkecuali dengan jabatan maupun amanah yang diemban, sehingga struktur organisasi sebagaimana yang telah dibahas dalam poin kedua artikel ini menjadi relevan apabila terkait dengan keabsahan jenjang karir di lingkungan PTNBH. Dengan tuntutan kepuasan masyarakat terhadap layanan publik, yang dalam hal ini adalah PTN-BH, tentu motivasi dan manusia itu sendiri menjadi penting dalam konteks ini untuk merelasikannya dengan pelayanan maksimal (Jati, 2014). Maka dimensi motivasi sendiri pada dasarnya mencakup nila inilai pemberdayaan (empowering) yakni ikut memberdayakan aparatur untuk ikut termotivasi dalam memberikan kinerja yang terbaik, nilai kepemilikan (ownership) yakni adanya rasa bertanggungjawab yang harus diemban dan dipikul bersama dalam upaya meningkatkan kompetensi, dan juga nilai keterikatan (involvement) aparatur untuk mengikuti berbagai macam parameter$\mathrm{p}$ a $\mathrm{r}$ a $\mathrm{m}$ e $\mathrm{t}$ e $\mathrm{p}$ e $\mathrm{n}$ i $\mathrm{ng} \mathrm{k}$ a $\mathrm{t}$ a $\mathrm{n}$ kinerja maupun proses pemberian pelayanan publik kepada masyarakat(Brown, 2001).

Salah satu cara untuk meningkatkan motivasi bagi para ASN khususnya PNS di lingkungan PTN-BH adalah dengan memberikan kepastian terkait dengan struktur organisasi sebagaimana telah dibahas dalam poin kedua. Manajemen PNS diatur dalam Peraturan Pemerintah No. 11 Tahun 2017 tentang manajemen Pegawai Negeri Sipil yang membagi jabatan menjadi tiga golongan yaitu Jabatan Pimpinan Tinggi (JPT), Jabatan Administrasi (JA), Jabatan Fungsional (JF). Ketiga jabatan diatas tidak hanya dapat diduduki oleh PNS melainkan ASN secara keseluruhan, hal ini berarti PPPK juga dapat menduduki ketiga jabatan tersebut, meskipun penulis menyoroti inkonsistensi penyebutan ASN dan PNS dalam PP tersebut, dimana judul PP adalah manajemen PNS namun didalam aturan mengatur mengenai ASN yang dengan demikian termasuk pula dengan PPPK.

PP Manajemen PNS tersebut juga mengatur mengenai Pejabat yang Berwenang (PyB) yaitu pejabat yang mempunyai kewenangan melaksanakan proses pengangkatan, pemindahan dan pemberhentian pegawai ASN sesuai dengan ketentuan peraturan perundang-undangan. Berdasarkan pengertian diatas, di lingkungan PTN-BH Rektor adalah Pejabat yang Berwenang (PyB), namun demikian aturan terkait dengan kewenangan Rektor baik di tingkat Undang-Undang maupun Peraturan Pemerintah tidak memberikan ketentuan secara tegas bahwa Rektor adalah PyB. Penetapan Rektor sebagai PyB diperlukan untuk mempermudah pemberian reward and punishment kepada SDM PTN-BH sesuai dengan otonomi pengelolaan perguruan tinggi badan hukum yang diamanatkan UU Perguruan Tinggi. Dengan penegasan Rektor selaku PyB akan mempermudah penyusunan kebutuhan dan analisis jabatan yang diperlukan guna meningkatkan daya saing PTN BH itu sendiri.

Adapun penyusunan kebutuhan dan analisis jabatan harus haruslah mempertimbangkan dinamika / perkembangan organisasi / lembaga. Analisis jabatan dan beban kinerja tersebut kemudian disusun oleh Instansi Pemerintah mengacu pada pedoman Menteri. Pedoman yang dimaksud adalah Permenpan-RB No. 25 Tahun 2016 jo Permenpan-RB No. 18 Tahun 2017 tentang Nomenklatur Jabatan Pelaksana Bagi Pegawai Negeri Sipil di lingkungan instansi Pemerintah. Disini penulis ingin menunjukkan bahwa frasa "mengacu pada pedoman" yang terdapat pada Pasal 6 ayat 1 PP No. 11 Tahun 2017 tentang Manajemen Pegawai Negeri Sipil ini kemudian dapat dianggap menjadi suatu penghambat dalam pembentukan dan pengesahan struktur organisasi dan nomenklatur jabatan di PTNBH. Mengapa demikian? Karena dalam lampiran Permenpan-RB No. 25 Tahun 2016 jo. Permenpan RB No. 17 Tahun 2017 tentang Nomenklatur Jabatan Pelaksana Bagi Pegawai Negeri Sipil di lingkungan instansi Pemerintah sebagai aturan pelaksana PP tersebut diatur jenis-jenis dan nomenklatur 
jabatan di lingkungan instansi pemerintahan dengan detail dan dengan nama-nama yang definitif.

Pembakuan nomenklatur ini memang merupakan pertimbangan utama dalam pembentukan Permenpan-RB tersebut, dimana nomenklatur jabatan di instansiinstansi pemerintah belum ada keseragaman antara jabatan dan kualifikasi pendidikan. Meskipun demikian, apabila merujuk pada analisis kebutuhan disesuaikan dengan kebutuhan masing-masing instansi dan disesuaikan dengan prinsip otonomi pengelolaan PTN-BH yang bermuara pada peningkatan kualitas dan daya saing, maka seharusnya pedoman yang disusun oleh Kementerian Pendayagunaan Aparatur Sipil Negara dan Reformasi Birokrasi ini hendaknya perlu dimaknai sebatas sebagai acuan layaknya arah kompas saja, dan tidak dimaknai secara letterlijk. Dengan demikian, tugas serta fungsi daripada setiap nomenklatur jabatan merujuk kepada Permenpan-RB tersebut namun PTN-BH dapat diberikan keleluasaan untuk mengembangkan struktur organisasinya dengan designasi nama yang berbeda sesuai dengan kebutuhan.

Diperlukan pula penegasan apakah bentuk kewenangan yang diberikan kepada pimpinan $\mathrm{PTN}-\mathrm{BH}$ merupakan bentuk kewenangan yang bersifat atributif sehingga dapat berlaku dan diakui oleh Instansi diluar Kemenristekdikti. Penulis berpendapat bahwa kewenangan untuk membentuk struktur organisasi merupakan atribusi dari Undang-Undang No 12 Tahun 2012 dimana Pasal 65 ayat 3 memberikan kewenangan kepada PTN-BH untuk membuat tata kelola dan mengambil keputusan secara mandiri. Dengan demikian struktur dan nomenklatur yang dibuat secara mandiri oleh PTN-BH harus diakui oleh Kementerian terkait.

\section{Simpulan}

Tidak dapat dipungkiri bahwa dibentuknya PTN-BH merupakah ikhtiar Pemerintah untuk meningkatkan daya saing PTN dalam persaingan global. Otonomi Pengelolaan Perguruan Tinggi Negeri Badan Hukum perlu mempertimbangkan ketiga aspek terkait Sumber Daya Manusia, yakni struktur organisasi, nomenklatur jabatan dan jenjang karir bagi ASN yang berada di lingkungan PTN-BH. Setelah membahas poin-poin diatas pernulis berpendapat diperlukan suatu Peraturan Pemerintah yang mengatur mengenai Pengelolaan Sumber Daya Manusia di lingkungan PTN-BH sehingga tidak terjadi benturan dengan Permenpan-RB terkait dengan manajemen ASN.

Opsi kedua adalah dengan menyamakan persepsi terkait tata kelola dan struktur kelembagaan di seluruh PTN-BH agar mengikuti acuan dalam Permenpan-RB tentang Manajemen ASN. Namun disini Penulis lebih condong kepada opsi yang pertama mengingat atribusi otonomi pengelolaan PTN-BH sudah diatur dalam Undang-Undang No. 12 Tahun 2012 tentang Perguruan Tinggi dan seyogyanya seluruh kementerian terkait mematuhi ketentuan peraturan perundang-undangan yang lebih tinggi

\section{DAFTAR PUSTAKA}

Alma, B., \& Hurriyati, R. (2008). Manajemen corporate dan strategi pemasaran jasa pendidikan : fokus pada mutu dan layanan prima. Bandung: Alfabeta. Retrieved from https://books.google.co.id/books?id=8K0O AQAAMAAJ\&q $=$ buku + alma $+2009 \& d q=b$ uku+alma $+2009 \& h l=e n \& s a=X \&$ redir_esc $=\mathrm{y}$

Brown, L. (2001). Measuring Capacity Building. North Carolina: Carolina Population Center.

Daftar 100 Peringkat Perguruan Tinggi NonPoliteknik di Indonesia tahun 2017 | Direktorat Jenderal Kelembagaan Iptek dan Dikti. (n.d.). Retrieved March 23, 2017, f $\quad r \quad r \quad m$ http://kelembagaan.ristekdikti.go.id/index. $\mathrm{ph} \mathrm{p} / 2017 / 08 / 18 / \mathrm{daftar}-100$ peringkatperguruan-tinggi-non-politekniktahun-2017/

Irawan, B. (2011). Diskresi sebagai Tindak Pidana Korupsi: Kajian Kriminologi dan Hukum terhadap Fenomena Pejabat Otoritas. Mimbar Hukum, 27(2), 143149.

J.H.A, L. (1995). Over theTheorie van en Stelling Staatsrecht. Amsterdam: Mahabaratha.Jati, W. R. (2014). Energizing Bureaucracy Sebagai Model Pengembangan Karir Aparatur Berbasis Meritokrasi Di Era Uu Asn: Tawaran Perspektif Alternatif. Jurnal 
Kebijakan Dan Manajemen, 8(1), 7385.OECD. (2010).

OECD Report, Executive Summary on Higher Education in Egypt. Retrieved from https://www.oecd.org/education/skillsbeyond-school/44820471.pdf

Purwandani, D., \& Sutarsih, C. (2016). Pengaruh mutu layanan sarana dan prasarana terhadap kepuasan mahasiswa di fakultas pendidikan teknologi dan kejuruan universitas pendidikan indonesia, 8090.

QS World University Rankings 2018 | Top Universities. (n.d.). Retrieved March 23, 2017 , from ht tps:// www. topuniversities.com/universityrankings/world-university-rankings/2018

Ridwan, H. (2013). Hukum Administrasi Negara. Jakarta: PT Raja Grafindo Persada.

Shattock, M. (2002). ReBalancing Modern Concepts of University Governance. Higher Education Quarterly, 56(3), 235244. https://doi.org/10.1111/1468-2273.00215

Tamanaha, B. Z. (2007). A Concise Guide to The Rule of Law. New York: St John University School of Law.

Top Universities in Indonesia | 2017 Indonesian University Ranking. (n.d.). Retrieved $\mathrm{M} \mathrm{a} \mathrm{r} \mathrm{c} \mathrm{h} \mathrm{23,} 2017$, f r o m https://www.4icu.org/id/

Wahab, R. (2004). Perguruan Tinggi Badan Hukum Milik Negara (PT-BHMN) ditinjau dari perspektif filosofis dan sosiologis. $\mathrm{R}$ e t r i e v e d from h t p : / / staff.uny.ac.id/sites/default/files/penelitian /Rochmat Wahab, M.Pd.,MA. Dr., Prof./PTBHMN(R).pdf 